\title{
The influence of transport infrastructures on land-use conversion decisions within municipal plans
}

\author{
Miguel Padeiro ${ }^{a}$ \\ University of Lisbon, Portugal
}

\begin{abstract}
Transit-oriented development (TOD) is one of the most popular means of public intervention in the field of spatial planning, which aims at reducing land consumption caused by urban sprawl. In this paper, a logit model is computed to assess whether the Municipal Master Plans approved during the 1990s in the Lisbon region (Portugal), currently in force, contemplated public transit stations as a relevant requirement for the location of the planned urban expansion areas and, more specifically, for the conversion of non-urban areas to artificialized areas. It is shown that TOD was not taken as a preferential approach, suggesting that there may be at the outset an inherent resistance to public injunctions on limiting land-use conversion, regardless of other obstacles frequently mentioned.
\end{abstract}

\section{Introduction}

In recent decades urban sprawl has resulted from population growth, changes in the economic system, and a general increase in living standards in western countries. In Portugal, the urban population rose from 27.7 to $54.1 \%$ between 1975 and 2002 (UNDP 2004), whereas urbanized areas grew by $41 \%$ (IA 2005). This development was followed more recently by the reemergence of concerns about land-use regulation, which led to the generalization of growth control tools (Henderson 1991, Wu and Cho 2007). Transit-oriented development (TOD) is one prominent strategy to achieve urban sustainability (Curtis 2012, Cervero et al. 2002). Of the possible approaches linked to TOD, zoning-based land-use control is one of the most popular. Typically, it consists of guiding urbanization to areas located close to public transit stations, reducing at the same time land-use conversion in the periphery.

Such policies have inevitably led to questions about the ability of spatial planning to reduce peripheral land artificialization. Evaluating TOD policies often involves estimating landuse conversions. However, in this paper the question is not whether public authorities are able to reduce land consumption, but whether they actually seek to do it through planning policies. More precisely, the aim is to test proximity to transit stations as a determinant of the location of developable areas. In Portugal, land consumption reduction is a clearly stated goal in the latest national and regional planning documents produced in the 2000s; however, the Municipal Master Plans (PDMs, Planos Directores Municipais) approved in the 1990s are still in force today and play the major role in land-use policies.

This paper is structured as follows: section 2 presents a literature review, focusing both on the ability of TOD to reduce peripheral land consumption and on barriers against its implementation; section 3 presents the study area and describes the planning context; section 4 discusses the methodological framework; section 5 presents the results; and section 6 concludes.

\section{Barriers against TOD in reducing land consumption}

Associated with land-use regulations, TOD is commonly justified as a key approach to reducing land consumption by concentrating developable areas close to transit stations. However, the results of TOD and land regulation policies have in some cases been disappointing. While it is true that integrating transport and urban planning may help reduce land consumption in urban fringes (Arrington and Parker 2001), there may be a difference between strategies encouraging development near infrastructures and those that limit growth; the two approaches are rarely associated. As part of the latter ones, a more restrictive growth management policy may reduce the amount of new construction by $45 \%$ when compared to no growth management policies (Mayer and Somerville 2000). In five western states of the United States, the total supply of developed land was reduced by 10\% between 1982 and 1997 (Wu and Cho 2007). On the other hand, some targeted growth policies did not provide any evidence of positive effects. Areas located inside and outside containment boundaries may undergo a similar evolution (Kline and Alig 1999). In Copenhagen, the Finger Plan that has led all of the 20th century's spatial planning policies since the 1930s has not proven effective in many peripheral areas (Swaffield and Primdahl 2006, Vejre et al. 2007), despite some good results. In some cases, second homes may be built under a hobby-farm status (Daniels and Nelson

a jmpadeiro@campus.ul.pt 
1986, Kline and Alig 1999), which may lead to proliferation of houses, especially outside the containment boundaries. This "leapfrog" phenomenon (Lichtenberg 2011) is strongly associated with functional changes in rural-urban fringes. Finally, Caspersen et al. (2006) investigated the differences between cities with and without a Finger Plan. Concerning peripheral open land preservation, no significant difference was detected. Hence, it seems that the best results are achieved when containment policies are combined with growth planning in targeted areas (Irwin et al. 2003) or when incentive-based programs exist (Towe et al. 2008). In such cases, the goal of reducing construction is reached (Fischel 1987, Carruthers 2002).

Several reasons have been highlighted to explain such lukewarm results.

- Land-use conversion depends on numerous factors that are not targeted by TOD. After decades of urban growth, motorization, road investments, and labor specialization, the land use-transport relationship has become much more complex. The area where urban pressure may potentially be exerted has been enlarged (Duranton and Turner 2008, Baum-Snow 2007), and so has the set of determinants of land-use conversions (Pérès and Gaussier 2010, Carrión-Flores and Irwin 2004, Chakir and Parent 2009).

- Multiple barriers may hamper the integration of transport and spatial planning (Carruthers 2002, Cervero et al. 2002, Curtis 2008, Headicar 2003, Williams et al. 2000, Stead and Meijers 2009, Geerlings and Stead 2003). Organizational, institutional, legal, social and cultural, and resource-based "side effects" and physical barriers may coexist in the same local context (Banister 2005). Financial and political barriers (Cervero et al. 2002, Barroso 2006) are also frequently pointed out. For instance, in periods when financial resources are low and spatial planning is not given a high priority, land consumption is likely to increase (Caspersen et al. 2006).

- Urban fragmentation and sprawl are mainly due to the lack of execution, monitoring, and appraisal tools (Catita 2009). This suggests that municipalities are facing forces-market, individuals, conflicts of uses - that hinder the implementation of local planning policies. On the one hand, deregulation and speculation might increase developable areas outside urban boundaries (Domingues 2006, Woodcock et al. 2011). According to this perspective, the market acts as a constraint force and public authorities struggle to fix its flaws and inefficiency (Munneke 2005, Wu and Cho 2007, Brueckner 1990). On the other hand, lo- cal resistance to densification in urban areas leads to the inability to enhance development in these areas in order to save peripheral ones (Searle 2007), acting in parallel with real estate and economic pressures on peripheral open spaces (Filion and McSpurren 2007, Dumbaugh 2004). Parochialist planning is thus given a role that obstructs rising density within areas where TOD could be implemented.

However, such explanations might not be sufficient. Sometimes containment boundaries go along with local restrictions on growth (maximum heights and densities, floor area ratios), dooming urban densification to failure (Pendall et al. 2002, Dowall 1982, Levine 2006, Dowall 1984). In addition, excess of developable areas (Pendall 2000) and high local demographic projections are frequently interpreted as a consequence of the fragmentation of local government (Ascher 2007, Freilich et al. 2010), suggesting that metropolitan organization should be revised to achieve large-scale goals. While it may be an acceptable option in some cases, the main shortcoming of such an argument is twofold: (1) it fails to recognize that inadequate local decisions might be the source of undesired metropolitan-scale evolutions, independent of territorial configurations; and (2) it supports a less pragmatic and more divisive way, as metropolitan institutional reorganization is not consensually seen as an advisable reform involving several years - and sometimes decades - of public discussion. Here, our hypothesis is that the plans made by public authorities may not put TOD into practice, thus allowing land artificialization to unfold wherever there is available land. Such a gap does not therefore stem from contradictory forces that weigh on public decisions. It may rather derive from the unsuitability of the decisions, which should be evaluated taking their organization context as granted. Indeed, the current debate tends to ignore the actual involvement of planning decisions in the production of barriers (Woodcock et al. 2011), despite the diversity of situations ranging from voluntarism to "do-nothing" attitudes (Millward 2006). Urban planning rarely undertakes effectively integrated policies (Glaeser and Ward 2009, Melia et al. 2011), but this fact is rarely measured.

Our research question lies in the probability that a land plot undergoes a PDM-based land-use conversion decision. Zoning-based policies are frequently included as explanatory variables in econometric models (Pérès and Gaussier 2010, Sanchez 2004). Sometimes they are not even included (Fang et al. 2005, Chakir and Parent 2009). What matters here is not the set of land-use conversion determinants; the planning option is the dependent variable. This study aims to analyze the role of municipal planners in establishing developable areas, considering the reduction of peripheral open land-use con- 
version as a goal. Actual TOD cases are frequently examined with a view to identifying best practices, specific constraints, or even impacts on a large variety of issues. However, no study was found to examine and measure whether TOD was actually implemented.

\section{Study area and planning context}

The Lisbon Metropolitan Area (LMA) extends over 3,130 $\mathrm{km}^{2}$ (3\% of the national territory) on both sides of the river Tagus on the West Coast of the Iberian Peninsula (Figure 1). It includes 18 municipalities divided into 203 parishes, with 2.8 million inhabitants in 2011 ( $26 \%$ of the country). This NUTS II Region (Nomenclature of Territorial Units for Statistics, level 2 ) is therefore the capital region of a highly centralized country, with more than twice the population of Oporto, the second Portuguese conurbation. It accounts for more than 36\% of the national gross domestic product (GDP), concentrating key economic activities. LMA is also characterized by highly valued landscapes, encompassing a complex topographic system, coastal areas, wetlands, forestry and agricultural patterns. Urban pressure has been struggled against by national authorities, with preservation policies promoting value creation on a touristic basis.

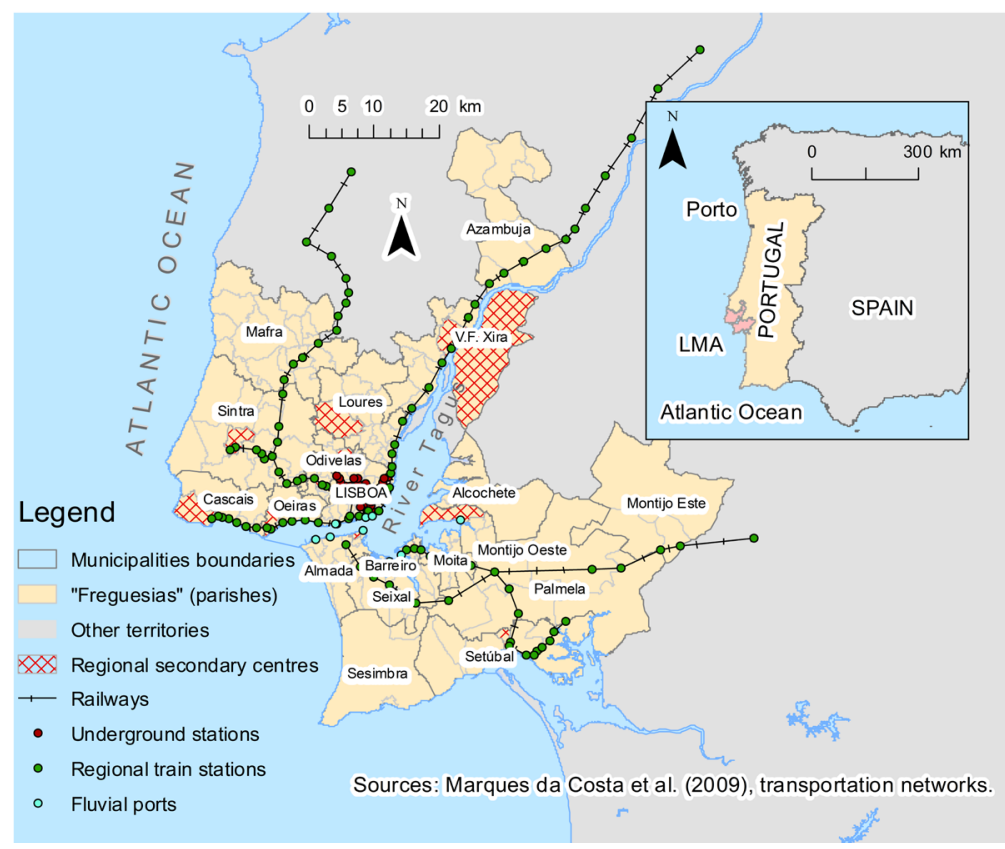

Figure 1: Lisbon Metropolitan Area and transit lines.

Regional land artificialization emerged during the 1990s as a central issue: whereas densely built-up areas occupied about $5 \%$ of the LMA territory in 1995, they reached $8.9 \%$ in 2007. At the same time, fragmented and dispersal areas reached about
9\% each (Bettencourt 2009). Along with industrial areas, the total built-up area accounted for 42\% of the LMA in 2007. Such an increase of artificial land must be considered within the context of road investments. In fact, highways used to be almost absent from Portugal in the 1980s. European funding and national strategic policies have allowed for massive investments since the 1990s, so nowadays the LMA has the highest motorway density among European NUTS II, with more than $220 \mathrm{~km}$ per $1,000 \mathrm{~km}^{2}$ (Eurostat 2012). The strong correlation between fragmented urban development and the expansion of such an oversized regional highway system has been outlined by several authors (Portas et al. 2007, Domingues 1999, Soares 2003), and must be linked to the ability of the spatial planning system to guide urbanization within the metropolitan area.

In 1982 the creation of the PDM put an end to decades of absolute centralization of urban planning policies (Alden and Pires 1996), transferring spatial planning competencies to the municipalities. PDM was given the major role of "translating the goals to be achieved for the social and economic development of the municipality" (Article 3, Law-Decree 208/82). It is a compulsory document, prepared and approved by local governments after a final public consultation, and finally ratified by central authorities. Initially defining goals for approximately 10 to 12 years, it includes: (1) the regulation; (2) a regulation map defining land use (generally with maximum heights and densities) and the main Operational Units for Planning and Management (UOP, Unidades Operacionais) for further investment programming; (3) a map of easements and restrictions; (4) urban plans for small areas within the municipality; and (5) urban detailed plans for even smaller areas. In the PDM, land-use conversion is therefore merely defined by the regulation map. The PDM also includes investment programs defining current and future land-use areas in a classical functional zoning approach. The implementation of the PDM is executed by the municipality.

The vast majority of PDMs were produced in the 1990s, and nearly all of them are still in force today. Meanwhile, two supra-level strategic plans were approved in the 2000s: the PROT-AML (Regional Plan for the LMA) in 2002 and the PNPOT (National Programme for Spatial Planning) in 2007. The PNPOT establishes the main guidelines and principles to be followed, with six strategic goals (biodiversity, competitiveness, polycentrism, equity, networks, public participation). The PROT-AML is given a pivotal role between the PNPOT and the PDM by identifying the main areas and spatial patterns (territorial model, preservation corridors, desired metropolitan dynamics) for promoting the national strategic goals. Finally, the PDM was merely defined by the 1998 Law for Territorial Planning to locally translate the regional and national strate- 
gies. However, the fact that all of the PDMs were approved much earlier (and that the PNPOT was made after the PROTAML) has brought about difficulties for implementing the supra-level strategies, despite some small modifications made in the PDMs after 2008 in order to adapt local plans. On the whole, the PDM's zoning method conflicts with the strategic approach promoted by the more recent regional and national plans. The ongoing revision of almost all of the PDMs (now involving both municipalities and regional authorities) is seen as the only way to bring clarity and coherence, but most of them are now undergoing a several-year revision process.

Finally, the Ecological or Agricultural National Reserves (REN and RAN) were created by Law Decree in 1982-83 (and revised in 1990) to prohibit construction on highly valued agricultural and ecological land. The delimitation of protected areas is proposed by the municipalities and then approved by the Council of Ministers after the opinion of specific committees involving regional and national level representatives. Such spatial restrictions have been strongly criticized because of their inconsistencies (Pardal 2002, Pardal 2004, Magalhães 2001, Soares de Albergaria 2006), but they are still binding on PDMs.

In practice, PDMs have not been effective for several reasons. The first is the lack of monitoring and appraisal, as well as the oversized developable areas that can lead to urban dispersal (Portas et al. 2011, Carranca and Castro 2011, Gonçalves 2009). Another reason is that many PDMs were frequently given partial adjournments in order to implement projects of national interest (PIN: Projectos de Interesse Nacional), such as highways and public commodities, or even to promote new touristic projects and the extension of existing industrial units, implying in several cases the downgrading of RAN-REN areas (Gonçalves 2009). Modifications of PDMs are also due to a high level of political corruption that tends to promote new developments in previously undevelopable areas (Lima 2011). Despite the fact that nearly $50 \%$ of the total LMA $\left(1,483 \mathrm{~km}^{2}\right)$ is under protection by RAN and/or REN, the National Reserves have not completely prevented these areas from being overlapped by bribery-based developments. Finally, the PDM is now given a low degree of autonomy, insofar as central authorities are not obliged to execute investments and programs planned by PDMs (Gonçalves 2009). .

\section{$4 \quad$ Method}

\subsection{Data}

Several statistical and geographic sources were used. Vector cartographic data from all LMA's $17 \mathrm{PDMs}^{1}$ were used (Figure 2). However, PDMs have no standard nomenclature, nor a similar level of accuracy. For example, "developable areas" are sometimes distinguished between "low," "medium," and "high" housing density, while no further specification is provided in other PDMs. Despite the fact that this would erase some more accurate data, all PDM nomenclatures were unified to allow for comparisons. In fact, while it is true that TOD is largely based on densities, non-TOD policies can be measured without them. When developable areas are defined in peripheral areas by local governments in terms of land-use conversion, they involve urban sprawl, independent of density. In addition, vector cartographic data from RAN and REN National Reserves were used and transformed into a parish-level database because of some concerns about its reliability at a finer scale.

The COS- $90^{2}$ land-use database was produced by the $\mathrm{Na}$ tional Centre for Geographical Information (CNIG), based on 1985-1987 satellite images (Caetano et al. 2008). However, its coverage is rather limited, as data are missing in some municipalities $^{3}$, restricting the study area (Figure 3). From the 203 parishes included in the LMA, only 171 are covered to over $70 \%$ by COS- 90 . Despite this methodological constraint, the total area represents $73.4 \%$ of the LMA territory, accounting for $88.6 \%$ of its population in 1991. It thus allows for a good sampling and ensures the validity of the model. Additionally, most of the uncovered area is not served by any public railway line. The only one (West Line) is far from being as efficient as the remaining lines, being thus quite marginal in the LMA transportation system. As a consequence, if the model is not absolutely accurate, it will tend first and foremost to underrate the absence of TOD in municipal planning.

Public transit stations in the LMA were identified, referring to the 1990s. Thirty-seven subway stations built before 2002 were included; at the time of PDMs' approvals, most were built and a few were already under project. One hundred and two railway stations belonging to six regional and national lines were identified, as well as Lisbon airport and nine river ports, which provide the Tagus crossing and retain a leading role in journeys to work, with 30 million passengers per year recorded in 2005 (Marques da Costa 2007). Highway access ramps were also listed, based on the Navteq database.

\footnotetext{
${ }^{1}$ LMA included 17 local governments in the early 1990s. However, Loures, north of Lisbon, was divided into two different municipalities (Loures and Odivelas) in 1998.

${ }^{2}$ The COS-90 (Carta de Ocupação do Solo) database is open access and can be downloaded at http://www.igeo.pt/produtos/CEGIG/COS.htm.

${ }^{3}$ A cartogram, including missing leaves, can be found at http://www.igeo.pt/produtos/CEGIG/cos_cartograma.htm.
} 


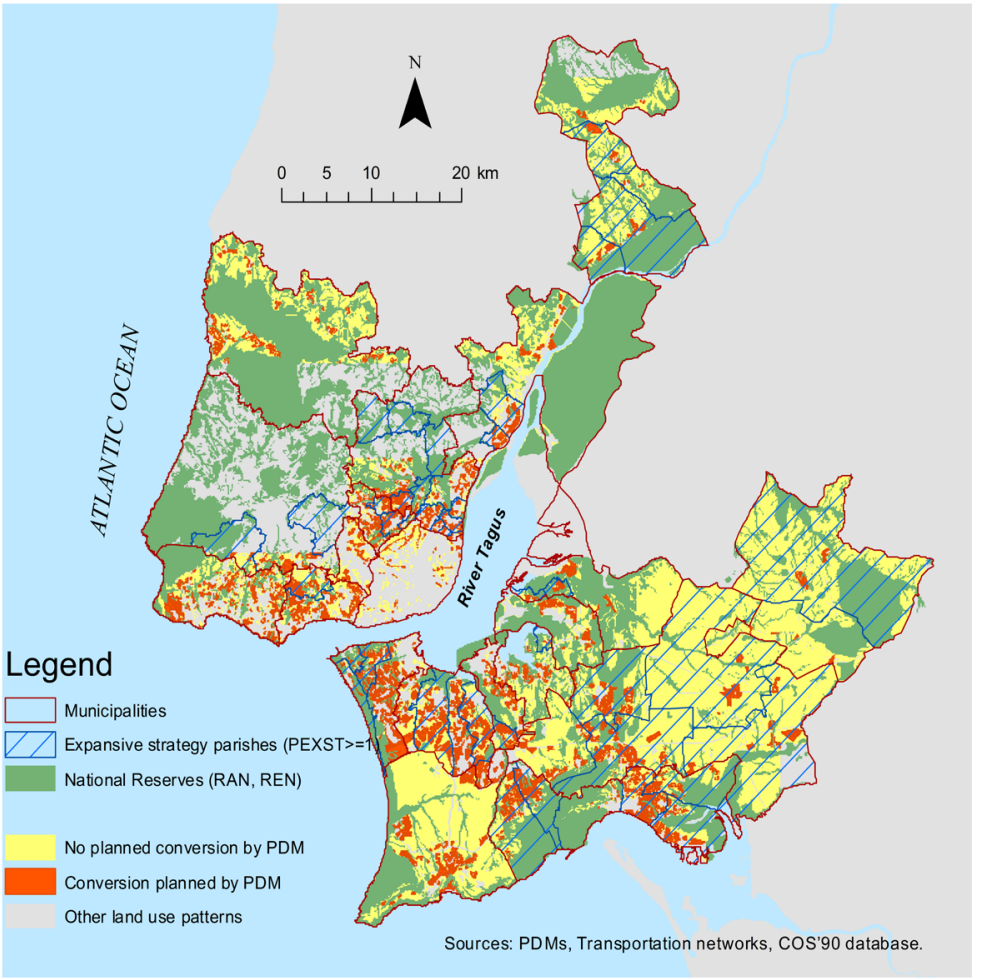

Figure 2: Land-use conversion planned by municipalities' PDMs in the LMA.

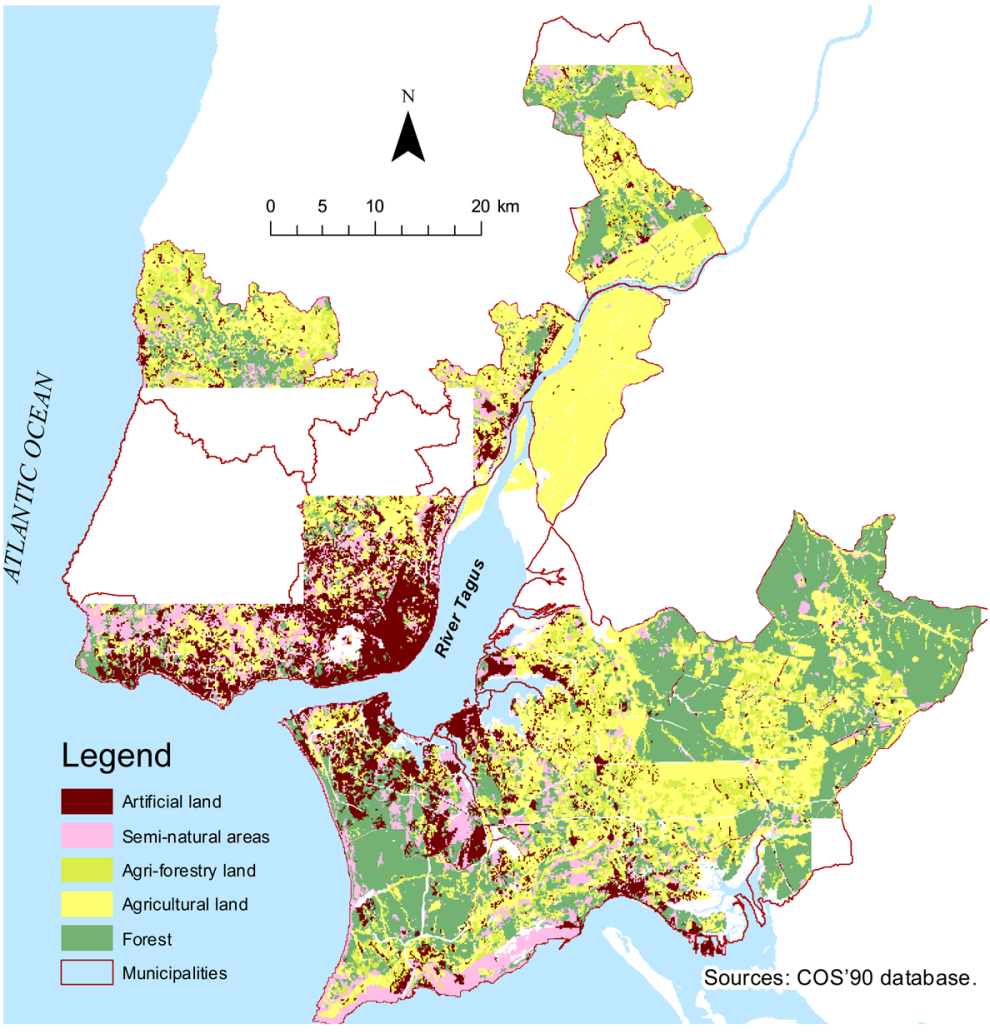

Figure 3: Artificial areas and open land in the LMA in 1990.

Finally, 1:25,000 scale maps drawn up by the Portuguese Geographic Institute (IGP) were used to extract detailed information about slopes.

\subsection{A logit model of planned land-use conversions}

To find empirical evidence of integration between transit stations and PDM-based land-use options, a logit model was computed. Each site is defined as a given PDM-based landuse area. Sites have a variable size, unlike the grids of cells commonly used in the literature. Sites have nevertheless been chosen as units, rather than the cells, in order to integrate the site size as a control variable. The question relies on the probability of a given site being considered a developable area, according to various location factors and taking into account the distance from transit stations. A logistic model was computed using SAS 9.2's logistic procedure to predict the probability of PDMs' projected land-use conversion (Equation 1):

$P C O N V_{i}=\log \left(\frac{P}{1-P}\right)=\beta X_{i}+\varepsilon_{i}$

where $P C O N V_{i}$ is the log transformation of the probability of a site $i$ being established as a developable area in the PDM and $P$ represents the probability of planning land-use conversion in the PDM; thus, the term $P /(1-P)$ represents the odds of a landuse conversion event occurring in the PDM. $X i$ represents the independent variables, $\beta$ represents the estimated coefficients, and $\varepsilon_{i}$ is the error term. The logit transformation is used to transform discrete outcome data (conversion/no conversion) into a continuous value that can be predicted by a linear regression equation (Tabachnick and Fidell 2000).

The dependent variable $P C O N V$ includes all sites that respect both conditions: (1) they were classified by the COS-90 database as open land (e.g., agricultural, forest, agri-forestry, or semi-natural area); and (2) they were not converted during the period between the COS-90 database and PDM approvals (they can't therefore be classified as "existing urban areas" in the PDMs). The total projected land-use conversion area extends over $177 \mathrm{~km}^{2}$. As $336 \mathrm{~km}^{2}$ were already artificialized in the COS-90 database and $200 \mathrm{~km}^{2}$ were classified as artificialized areas in the PDMs, projected land-use conversion areas represent a 33\% increase of the artificialized area.

The predictors can be divided into three categories (Equation 2).

$P C O N V_{i}=\beta_{0}+\beta_{1}\left(U R B_{i}\right)+\beta_{2}\left(S R N_{i}\right)+\beta_{3}\left(L O C_{i}\right)+\varepsilon_{i} \quad$ (Eq. 2)

Here, $U R B$ is a parish-level set of urban specific variables, $S R N$ is a site-level set of variables describing surroundings and physical patterns, and $L O C$ is the set of location variables. As the main focus of this study is to assess whether transport-related location influenced planning decisions, the $L O C$ category includes the main independent variable, whereas the $U R B$ and $S R N$ categories were used as control variables. All variables are 
reported in Table 1. It is worth noting that variables of commonly used microeconomic choice (Carrión-Flores and Irwin 2004, Irwin and Bockstael 2004) were not included, as our question is not whether the site was actually converted but only whether conversion was planned by the PDMs.

Proximity to transit stations was measured using sites' centroids and straight-line distances. Differences between Euclidean and network distances are not significantly high, allowing for a Euclidean distance-based method (Apparicio et al. 2008). Moreover, the existence of numerous spontaneous paths outside road networks would not be addressed by shortest path calculations, inducing some bias in distances and buffers. As a second step, all sites were classified depending on their distance to the nearest transit station: the $0-800$ m class is commensurate with a 10-minute walk that is generally considered as a reference pedestrian time when defining transit-oriented development areas (Renne and Wells 2005, Renne 2008, Olaru et al. 2011); the other two thresholds (1,200 and 2,000 m) are also commonly used (Cervero 1984, Yigitcanlar et al. 2007, DeCoursey and Athey 2007). Other distance categories were chosen for comparisons.

A Box-Tidwell approach was used to test the assumption of a linear relationship between continuous predictors and the logit transformation of the dependent variable (Hosmer and Lemeshow 2004, Tabachnick and Fidell 2000). Nonlinearity was found for the distance variables (disL and disSC). As a consequence, both were transformed into logs.

Finally, as the presence of spatial autocorrelation in the error term was suspected, a Moran's I was computed based on a $k$ nearest neighbors analysis $(k=8)$ using GeoDa software (Anselin 2001). The autocorrelation was confirmed, as significant values were found $(\rho=0.432, \mathrm{p}<.0001)$. A spatially lagged variable $(S L V)$ was then generated using GeoDa package once again. The $S L V$ consists of a new regressor added to the model based on a spatial weight matrix that relates the dependent variable at a given location to its value in other spatial units (Anselin 1988). 
Table 1: Definition of variables and summary statistics.

\begin{tabular}{|c|c|c|c|c|}
\hline Group & Variable Name & Description & Mean & Std \\
\hline DEP & PCONV & $\begin{array}{l}\text { Planned conversion in the municipal master plan: if converted into } \\
\text { expansion area, } P C O N V i=1 \text {, otherwise } P C O N V i=0 .(s, 1,2)\end{array}$ & 0.216 & 0.411 \\
\hline LOC & BUFF800 & Belonging to a buffer $0-800 \mathrm{~m}$ : yes 1,0 otherwise $(\mathrm{s}, 1,6)$ & 0.055 & 0.228 \\
\hline LOC & BUFF1200 & Belonging to a buffer $800-1,200$ m: yes 1,0 otherwise $(s, 1,6)$ & 0.071 & 0.257 \\
\hline LOC & BUFF2000 & Belonging to a buffer $1,200-2,000$ m: yes 1,0 otherwise $(s, 1,6)$ & 0.143 & 0.350 \\
\hline LOC & BUFF5000 & Belonging to a buffer 2,000-5,000 m: yes 1,0 otherwise $(\mathrm{s}, 1,6)$ & 0.361 & 0.480 \\
\hline LOC & BUFF10000 & Belonging to a buffer $5,000-10,000 \mathrm{~m}$ : yes 1,0 otherwise $(\mathrm{s}, 1,6)$ & 0.233 & 0.423 \\
\hline LOC & DisHW & $\begin{array}{l}\text { Natural log of distance }(\mathrm{km}) \text { from parcel to nearest highway ramp }(\mathrm{s} \text {, } \\
1,5)\end{array}$ & 4.810 & 3.775 \\
\hline SRN & Avail & $\begin{array}{l}\text { Availability of potentially developable land: sum of agricultural, agri- } \\
\text { forestry, forest, and semi-natural areas within the parish, measured in } \\
\% \text { of the parish total area that is included in a } 0-800 \mathrm{~m} \text { buffer }(\mathrm{p}, 1)\end{array}$ & 0.820 & 0.182 \\
\hline SRN & Siteslope & Site average slope (degrees) $(s, 7)$ & 4.787 & 5.275 \\
\hline SRN & LogDisL & $\begin{array}{l}\text { Natural log of distance }(\mathrm{km}) \text { from site centroid to Lisbon City bound- } \\
\text { aries }(\mathrm{s}, 1)\end{array}$ & 2.744 & 1.520 \\
\hline SRN & LogDisSC & $\begin{array}{l}\text { Natural log of distance }(\mathrm{km}) \text { from site to secondary centers }(\mathrm{s}, 1)- \\
\text { secondary centers chosen based on (Marques da Costa et al., 2009) }\end{array}$ & 2.185 & 0.859 \\
\hline SRN & SC2000 & $\begin{array}{l}\text { Belonging to a secondary center buffer: } 1 \text { if located }<2000 \mathrm{~m} \text { from a } \\
\text { secondary center, } 0 \text { otherwise }(\mathrm{s}, 1)\end{array}$ & 0.060 & 0.238 \\
\hline SRN & S_Size & Site size $\left(\mathrm{km}^{2}\right)(\mathrm{s}, 1)$ & 0.039 & 0.252 \\
\hline SRN & SRD & $\begin{array}{l}\text { Distance to the nearest urban fabric parcel in the surroundings }(<800 \\
\mathrm{m} \text { from site }=1,0 \text { otherwise). Here, urban fabric is represented by the } \\
\text { following PDMs classes: urban consolidated area, urban restructuring } \\
\text { area, economic areas, other artificialized area }(s, 1,2)\end{array}$ & 0.595 & 0.767 \\
\hline URB & PREVC & $\begin{array}{l}\text { Previous conversions: land use conversions from open land to urban } \\
\text { areas that occurred during the time between COS'90 and PDM ap- } \\
\text { provals, in } \% \text { of the open land }(\mathrm{p}, 1,2)\end{array}$ & 0.130 & 0.142 \\
\hline URB & DPOP91 & Parish density in 1991 , based on the parish total area $\left(\mathrm{pop} / \mathrm{km}^{2}\right)(\mathrm{p}, 3)$ & 929.160 & $1,917.740$ \\
\hline URB & IED & $\begin{array}{l}\text { IED }=\text { [individuals with high school completed] / [illiterate individuals } \\
+ \text { individual with primary school completed + individuals with second- } \\
\text { ary school completed] }(\mathrm{p}, 3)\end{array}$ & 0.048 & 0.079 \\
\hline URB & LNPOP91 & Natural log of population in 1991 in the parish $(\mathrm{p}, 3)$ & 8.843 & 1.104 \\
\hline URB & PEXST & $\begin{array}{l}\text { Municipal expansion strategy in the parish = expansion areas } / \text { urban } \\
\text { areas }(p, 1)\end{array}$ & 1.377 & 1.536 \\
\hline URB & PPAGROW & Annual population growth between 1981 and $1991(\%)(\mathrm{m}, 1,3,4)$ & 0.007 & 0.011 \\
\hline URB & RAN & Agricultural National Reserves: \% within the parish total area (p, 1,8$)$ & 0.156 & 0.164 \\
\hline URB & REN & Ecological National Reserves: \% within the parish total area $(\mathrm{p}, 1,8)$ & 0.333 & 0.236 \\
\hline URB & YEAR & $\begin{array}{l}\text { If municipal master plan was approved before } 1996,=1,0 \text { other- } \\
\text { wise (PDMs were approved in 1992-93-94-95, then } 97-98-99) \text {. The } \\
\text { distinction between the two periods is based on the 1995-97 temporal } \\
\text { break }(\mathrm{m}, 2)\end{array}$ & 0.544 & 0.498 \\
\hline SLV & SLV & Spatially lagged variable & 0.162 & 0.261 \\
\hline
\end{tabular}

Bracketed information is provided. Letters indicate the data level. p: parish-level data; m: municipality-level data; s: site-level data. Numbers indicate the source. 1: COS-90; 2: PDMs; 3: 1991 Population Census; 4: 1981 Population Census; 5: Navteq road network; 6: public transit networks (Carris, CP, Soflusa); 7: IGEOE military maps; 8: National Reserves Maps. 


\section{$5 \quad$ Findings}

\subsection{General results}

The first set of analyses examined the evolution of the total open land areas identified by COS-90 data, depending on the distance from sites to transit stations (Table 2). Each open land site may theoretically undergo three different evolutions: artificialization occurring before PDM is approved; conversion decision within the PDM; and no land-use conversion.

The data indicate that land-use conversions occurring before PDM approvals varied from $27.4 \%$ close to the stations to $3.8 \%$ in the $5-10 \mathrm{~km}$ buffer. However, the proportion increases again beyond $10 \mathrm{~km}$, reaching $9.8 \%$ and confirming that urban sprawl in peripheral areas and intensification of built-up areas near transit-served neighborhoods are concomitant. Even more interesting is the fact that PDM decisions on land artifcialization tended to lessen with distance to the stations, from $37.2 \%$ of the total open land area near them down to $4.1 \%$ at greater distances. At first glance, it seems PDMs tended to favor densification of well-served areas, hampering the artificialization of peripheral open land. However, when comparing PDMs' land-use conversions with previous actual conversions, up to $5 \mathrm{~km}$ they are almost equal, suggesting that on the whole the planning options did not aim to limit land artificialization. Indeed, the plans allowed for greater open land consumption than the actual previous land-use conversions, implying that enhancing urban development and ensuring high population growth were considered more important than the goal of mitigating urban sprawl and the loss of open land.

The most striking result to emerge from the data is that it was decided that nearly $70 \mathrm{~km}^{2}$ of open land should be preserved less than $1.2 \mathrm{~km}$ from the stations, while land artificialization within the $2-5 \mathrm{~km}$ class reaches an equal area. In an ideal TOD-based containment policy, those best-served areas would be preferred over the remote ones for accommodating developable areas. Based on LMA's 1991 net density (4,706 inhab. $/ \mathrm{km}^{2}$ ), more than 300,000 inhabitants could have been accommodated less than $1.2 \mathrm{~km}$ from a station. Despite its lack of accuracy, such an estimate gives an idea of what a real integration policy could have accomplished.
Table 2: Evolution of open land in different transport-related buffers.

\begin{tabular}{|l|l|l|c|c|c|}
\hline $\begin{array}{c}\text { Buffer } \\
(\mathbf{k m})\end{array}$ & $\begin{array}{c}\text { Sites } \\
\left(\mathbf{n}^{\mathbf{0}}\right)\end{array}$ & $\begin{array}{c}\text { Area } \\
\left(\mathbf{k m}^{\mathbf{2}}\right)\end{array}$ & $\begin{array}{c}\text { Land use } \\
\text { conversion } \\
\text { before } \\
\text { PDMs } \\
\left(\mathbf{k m}^{\mathbf{2}}\right)\end{array}$ & $\begin{array}{c}\text { Projected } \\
\text { land use } \\
\text { conver- } \\
\text { sion }\left(\mathbf{k m}^{2}\right)\end{array}$ & $\begin{array}{c}\text { No } \\
\text { openland } \\
\text { planned } \\
\text { conversion } \\
\left(\mathbf{k m}^{2}\right)\end{array}$ \\
\hline $0-0.8$ & 4,601 & 60.9 & 16.7 & 16.4 & 27.7 \\
\hline $0.8-1.2$ & 4,973 & 72.9 & 14.2 & 16.3 & 42.4 \\
\hline $1.2-2$ & 9,490 & 197.1 & 30.7 & 29.9 & 136.4 \\
\hline $2-5$ & 22,042 & 666.1 & 74.7 & 70.7 & 520.7 \\
\hline $5-10$ & 12,478 & 617.6 & 23.4 & 28.7 & 565.5 \\
\hline$>10$ & 7,419 & 411.7 & 40.4 & 15.4 & 355.9 \\
\hline TOTAL & 61,003 & $2,026.2$ & 200.1 & 177.4 & $1,648.7$ \\
\hline
\end{tabular}

\subsection{Estimation results}

As a second step, the logistic model was estimated, including only the distance variables (Table 3). The results are consistent with the previous ones. When additional variables are not taken into consideration, land-use conversions are more likely to be planned by PDMs in the best-served areas. The coefficients progressively decrease with distance, ranging from 2.106 within the closest buffer $(<800 \mathrm{~m})$ to 0.378 in the last one $(5-10 \mathrm{~km})$. The $\exp (\mathrm{B})$ column shows that the $p$ probability of a well-served open land site being converted by PDMs reaches $89.1 \%$, as $p=\exp (\mathrm{B}) /[1+\exp (\mathrm{B})]$. The probability that landuse conversion is projected in a PDM progressively decreases along with the distance to transit stations. However, the quality of predictions was not satisfactory at this stage, as the concordance percentage is rather low as well as the Nagelkerke $\mathrm{R}^{2}$.

To improve the reliability of the model, five sets of empical data were analyzed with all the variables previously identified. First, the logit model was estimated taking into account the open land as a whole. Then, the model was computed distinguishing all four open land-use types: agricultural land, for-

Table 3: Logit model including only the buffer variables.

\begin{tabular}{|c|c|c|c|}
\hline \multirow{2}{*}{ Intercept } & \multicolumn{3}{|c|}{ Open land } \\
\cline { 2 - 4 } & $\mathrm{B}$ & S.E. & $\operatorname{Exp}(\mathrm{B})$ \\
\cline { 2 - 4 } & $-2.348^{* * *}$ & 0,044 & 0.096 \\
\hline BUFF800 $(0,1)$ & $2.106^{* * *}$ & 0,060 & 8.217 \\
\hline BUFF1200 $(0,1)$ & $1.814^{* * *}$ & 0,057 & 6.135 \\
\hline BUFF2000 $(0,1)$ & $1.510^{* * *}$ & 0,052 & 4.526 \\
\hline BUFF5000 $(0,1)$ & $1.119^{* * *}$ & 0,048 & 3.062 \\
\hline BUFF10000 $(0,1)$ & $0.378^{* * *}$ & 0,053 & 1.459 \\
\hline
\end{tabular}

Number of observations: 46,273. -2 Log likelihood: 45,606. Nagelkerke $R^{2}$ : 0.088. Likelihood ratio test: 2,704, with 5 d.f. Concordance percentage: $55.3 \%$. Tie: 21.5 . 
est, agri-forestry and semi-natural areas.

The logit model fits the data well (Table 4). All chi-square statistics are significant, Nagelkerke's $\mathrm{R}^{2}$ always reaches 0.67 or 0.68 , and all the models show a high concordance percentage, equal to at least $93.9 \%$. The spatially lagged variable considerably improved the model, as the concordance percentage rose from $83.4 \%$ (without SLV) to $95.2 \%$ (with SLV included). Using a multiple regression procedure that included the variance inflation option (VIF), no concern was shown about multicollinearity among independent variables, with all VIF presenting low values and a maximum at 3.59 (Buff5000).

Regarding the main model (openland column), the coefficients for the variables describing surroundings and physical patterns appear to be rather in agreement with the literature. The likelihood of a land conversion decision in PDMs declined with site size, and the availability of potentially developable land. In the latter case, the existence of available land near a transit station should encourage municipalities to favour further development in the most accessible areas rather than in others. However, counter-intuitively, the coefficients for the variable $Y E A R$ indicated that land-use conversions were more likely to be planned in parishes where a PDM was approved later. Meanwhile, the coefficients rose with previous land-use conversions, which is consistent with (Wu and Cho 2007); they rose also with $\log$ of population in 1991, spatially lagged variable, and with educational index, which is a proxy for socioeconomic variables such as income, which is generally a significant variable in predicting land-use conversion (Kline and Alig 1999). The coefficients were also positively correlated with municipal expansion strategy, and increasing distances to the nearest urban fabric parcel. Although densely populated areas might be a deterrent (Carrión-Flores and Irwin 2004), the simple presence of residential land generally means that there are some basic infrastructures and services, in which case landuse conversions may be boosted.

Four results should be highlighted here:

- Projected land-use conversions were related neither to distance to highway entry points, nor to the distance from the Lisbon center and from the region's secondary centers. This means that the location of developable areas is widely spread and not in line with the predominant urban containment approach.

- The 1981-1991 annual population growth was found to have a negative effect on the conversion decision, contrasting with LogPop91 and PREVC variables. The variable PPAGrow is municipality-based, while the other two are based on parishes. Within a given municipality, larger developable areas may be established in the most densely populated parishes. However, when considering differences across municipalities, those with the most dramatic population growth might not increase further developable areas. This suggests that a contradictory attitude towards densification and landuse conversion may be adopted by a municipality. On the one hand, land artificialization is encouraged in consolidated urban areas in order to promote preservation in open land areas within the municipality. On the other hand, however, artificialization is hampered in highly developed municipalities, smoothing the way to land-use conversions in open land areas outside the boundaries.

- Ecological National Reserve coefficients were not statistically significant, implying that statewide protected areas did not induce a propensity to reduce land artificialization. In the context of the 1990s in Portugal, when urban planning was essentially technocratic with almost no citizen involvement, such results mean that the Ecological Reserve was seen more as a regulationbased prohibition tool than as an incentive for local governments to become aware of the need for saving open land and to adopt the national strategies locally. In locations where development was not prohibited by the REN, containment was no longer addressed. Contrasting with the REN, the RAN coefficient is negative and significant (at the 1\% level), reflecting the greater importance of agricultural issues in a recently urbanized country.

- Finally, as this study focuses on the role played by the distance to transit stations, the estimates for all buffers are particularly relevant. All things being equal, these buffers played an unexpected role in land-use conversion planning. Negative coefficients were found regarding all five buffers (from $<800 \mathrm{~m}$ to $5-10 \mathrm{~km}$ ), and it can almost be said that the further the rings are, the lower these coefficients become. Such estimations are completely different from the ones mentioned in Table 3. When the other variables are controlled for, the zoning-based effort made by municipalities to reduce open land consumption was not correlated with the proximity to infrastructure. Moreover, it appears to be correlated with greater distances: land-use conversion is therefore more likely to be planned by a municipality when the site is far from the transit network.

Compared to the main model, the partial models focusing on each of the previously defined land-use types (agricultural land, forest, agri-forestry land, and semi-natural areas) show not en- 
Table 4: Logit regression results with dependent variable $=\mathrm{PCONV}_{\mathrm{i}}$.

\begin{tabular}{|c|c|c|c|c|c|c|c|c|c|c|c|c|c|c|c|}
\hline & \multicolumn{3}{|c|}{ Open Land } & \multicolumn{3}{|c|}{ Agricultural Land } & \multicolumn{3}{|c|}{ Forest } & \multicolumn{3}{|c|}{ Agri-forestry land } & \multicolumn{3}{|c|}{ Semi-natural areas } \\
\hline & $\mathrm{B}$ & S.E. & Exp (B) & $\mathrm{B}$ & S.E. & Exp (B) & $\mathrm{B}$ & S.E. & $\operatorname{Exp}(B)$ & $\mathrm{B}$ & S.E. & $\operatorname{Exp}(\mathrm{B})$ & $\mathrm{B}$ & S.E. & $\operatorname{Exp}(\mathrm{B})$ \\
\hline Intercept & $-3.272^{* * *}$ & 0.332 & 0.038 & $-3.848^{* * *}$ & 0.492 & 0.021 & $-2.199^{* * *}$ & 0.757 & 0.111 & $-3.222^{* * *}$ & 0.982 & 0.040 & $-3.583^{* * *}$ & 0.785 & 0.028 \\
\hline BUFF800 $(0,1)$ & $-0.165^{*}$ & 0.098 & 0.848 & -0.031 & 0.151 & 0.970 & -0.254 & 0.207 & 0.776 & $-0.704^{* * *}$ & 0.279 & 0.494 & -0.148 & 0.255 & 0.862 \\
\hline BUFF1200 $(0,1)$ & $-0.424^{* * *}$ & 0.096 & 0.655 & $-0.348^{* *}$ & 0.147 & 0.706 & $-0.589^{* * *}$ & 0.197 & 0.555 & $-0.889^{* * *}$ & 0.272 & 0.411 & -0.237 & 0.252 & 0.789 \\
\hline BUFF2000 $(0,1)$ & $-0.428^{* * *}$ & 0.089 & 0.652 & $-0.281^{* *}$ & 0.135 & 0.755 & $-0.564^{* * *}$ & 0.181 & 0.569 & $-0.920^{* * *}$ & 0.244 & 0.398 & -0.361 & 0.242 & 0.697 \\
\hline BUFF5000 $(0,1)$ & $-0.422^{* * *}$ & 0.082 & 0.656 & $-0.229^{*}$ & 0.127 & 0.796 & $-0.492^{* * *}$ & 0.164 & 0.611 & $-0.985^{* * *}$ & 0.222 & 0.373 & $-0.489^{* *}$ & 0.230 & 0.613 \\
\hline BUFF10000 $(0,1)$ & $-0.432^{* * *}$ & 0.082 & 0.650 & $-0.245^{* *}$ & 0.124 & 0.782 & $-0.494^{* * *}$ & 0.159 & 0.610 & $-0.970^{* * *}$ & 0.223 & 0.379 & $-0.620^{* *}$ & 0.241 & 0.538 \\
\hline $\log \operatorname{Dis} L(\mathrm{~km})$ & -0.019 & 0.013 & 0.981 & $-0.041^{* *}$ & 0.021 & 0.960 & 0.009 & 0.033 & 1.009 & $-0.105^{*}$ & 0.062 & 0.900 & 0.022 & 0.022 & 1.022 \\
\hline LogDisHW (km) & -0.009 & 0.024 & 0.991 & 0.006 & 0.037 & 1.006 & -0.046 & 0.052 & 0.955 & -0.097 & 0.078 & 0.907 & 0.054 & 0.047 & 1.055 \\
\hline $\log \mathrm{DisSC}(\mathrm{km})$ & -0.036 & 0.036 & 0.965 & 0.002 & 0.053 & 1.002 & -0.090 & 0.082 & 0.914 & -0.067 & 0.112 & 0.936 & -0.115 & 0.087 & 0.892 \\
\hline Avail \% & $-0.320^{* *}$ & 0.148 & 0.726 & -0.032 & 0.240 & 0.968 & $-0.589^{*}$ & 0.312 & 0.555 & 0.377 & 0.528 & 1.457 & $-0.898^{* * *}$ & 0.299 & 0.407 \\
\hline Slope (degree) & -0.001 & 0.003 & 0.999 & -0.005 & 0.005 & 0.995 & 0.004 & 0.007 & 1.004 & 0.010 & 0.010 & 1.010 & -0.003 & 0.008 & 0.997 \\
\hline IED (index) & $0.365^{*}$ & 0.219 & 1.441 & 0.339 & 0.371 & 1.403 & 0.419 & 0.451 & 1.520 & 1.191 & 1.262 & 3.289 & 0.182 & 0.387 & 1.199 \\
\hline PEXST (\%) & $0.088^{* * *}$ & 0.017 & 1.092 & $0.095^{* * *}$ & 0.027 & 1.099 & 0.056 & 0.035 & 1.058 & $0.146^{* * *}$ & 0.048 & 1.157 & $0.074^{*}$ & 0.041 & 1.077 \\
\hline RAN (\%) & $-0.282^{*}$ & 0.161 & 0.754 & -0.309 & 0.232 & 0.734 & -0.041 & 0.352 & 0.960 & -0.616 & 0.522 & 0.540 & -0.477 & 0.400 & 0.620 \\
\hline REN (\%) & 0.164 & 0.103 & 1.179 & 0.249 & 0.155 & 1.283 & -0.066 & 0.219 & 0.936 & 0.320 & 0.294 & 1.377 & 0.263 & 0.262 & 1.300 \\
\hline PREVC (\%) & $1.038^{* * *}$ & 0.157 & 2.822 & $0.868^{* * *}$ & 0.247 & 2.383 & $1.157^{* * *}$ & 0.389 & 3.181 & 0.791 & 0.539 & 2.205 & $1.314^{* * *}$ & 0.310 & 3.720 \\
\hline $\operatorname{SC} 2000(0,1)$ & 0.009 & 0.078 & 1.009 & -0.034 & 0.120 & 0.966 & 0.008 & 0.186 & 1.008 & 0.100 & 0.286 & 1.105 & -0.054 & 0.152 & 0.947 \\
\hline S_Size $\left(\mathrm{km}^{2}\right)$ & $-1.666^{* * *}$ & 0.371 & 0.189 & $-1.515^{* *}$ & 0.641 & 0.220 & $-1.642^{* * *}$ & 0.568 & 0.194 & $-4.328^{* * *}$ & 1.406 & 0.013 & -1.422 & 0.893 & 0.241 \\
\hline $\mathrm{SRD}(\mathrm{km})$ & $-2.496^{* * *}$ & 0.087 & 0.082 & $-3.067^{* * *}$ & 0.149 & 0.047 & $-1.861^{* * *}$ & 0.151 & 0.156 & $-2.392^{* * *}$ & 0.229 & 0.091 & $-2.449^{* * *}$ & 0.206 & 0.086 \\
\hline Dpop91 (pop/km²) & $0.000^{* *}$ & 0.000 & 1.000 & $0.000^{*}$ & 0.000 & 1.000 & 0.000 & 0.000 & 1.000 & 0.000 & 0.000 & 1.000 & 0.006 & 0.000 & 1.000 \\
\hline Log Pop 91 & $0.160^{* * *}$ & 0.026 & 1.173 & $0.187^{* * *}$ & 0.040 & 1.205 & 0.066 & 0.060 & 1.068 & $0.178^{* *}$ & 0.082 & 1.195 & $0.244^{* * *}$ & 0.059 & 1.277 \\
\hline PPAGrow (\%/year) & $-7.574^{* * *}$ & 21.132 & 0.001 & $-5.815^{*}$ & & 0.003 & -0.937 & 4.398 & 0.392 & $-2.292^{* * *}$ & 6.652 & 0.000 & -1.077 & 4.767 & 0.000 \\
\hline Year $(0,1)$ & $-0.136^{* * *}$ & 0.042 & 0.873 & -0.081 & 0.066 & 0.923 & $-0.279^{* * *}$ & 0.087 & 0.757 & -0.136 & 0.132 & 0.873 & 0.018 & 0.094 & 1.018 \\
\hline Spatially lagged variable & $7.586^{* * *}$ & 0.084 & 1,970 & $7.703^{* * *}$ & 0.131 & 2,213 & $7.517^{* * *}$ & 0.170 & 1,838 & $8.265^{* * *}$ & 0.266 & 3,885 & $7.154^{* * *}$ & 0.180 & 1,279 \\
\hline $\begin{array}{c}\text { Number of observations } \\
-2 \text { Log likelihood } \\
\text { Nagelkerke } \mathrm{R}^{2} \\
\text { Likelihood ratio test } \\
\text { Concordance \% } \\
\text { Tie }\end{array}$ & $\begin{array}{l}46,273 \\
21,658 \\
0.675 \\
26,587 \text { wit } \\
95.2 \\
0.1\end{array}$ & 23 d.f. & & $\begin{array}{l}20,002 \\
9,230 \\
0.670 \\
11,203 \text { wit } \\
95.2 \\
0.1\end{array}$ & 3 d.f. & & $\begin{array}{l}11,853 \\
5,004 \\
0.670 \\
6,294 \text { wit } \\
95.6 \\
0.1\end{array}$ & d.f. & & $\begin{array}{l}6,294 \\
2,532 \\
0.687 \\
3,439 \text { wit } \\
96.1 \\
0.1\end{array}$ & d.f. & & $\begin{array}{l}8,112 \\
4,752.1 \\
0.674 \\
5,278 \text { wit } \\
93.9 \\
0.1\end{array}$ & 3 d.f. & \\
\hline
\end{tabular}

${ }^{*}$ significant at the $10 \%$ level, ${ }^{* *}$ at $5 \%$ level, ${ }^{* * *}$ at $1 \%$ level. 
tirely similar findings. No new positive significant estimation was found. Several variables are no longer explanatory ones. Distance to the Lisbon center becomes a negative significant variable when analyzing agricultural land and agri-forestry areas: agricultural sites were more likely to be converted in PDMs when the distance to the center is reduced. This finding does not apply to either forest or semi-natural areas. Pressure on open land near the central city is particularly intense in agricultural areas for which urban, cultural, and leisure functions are not as obvious as in forest areas, which are favored for tours and activities that also benefit from the existence of national parks.

The role of relative distances to transit stations is in all cases different from what is expected. In the case of agricultural areas, the probability of conversion increases with decreasing distance but is always less than 1 , with an insignificant coefficient between 0 and $800 \mathrm{~m}$. The same goes for forests. In the case of agri-forestry areas, the $\exp (\mathrm{B})$ value is below 0.5 in the first buffer $(<800 \mathrm{~m})$ and for semi-natural areas the relationship is not significant. When all other factors are controlled for, the probability of open land-use conversion is greater outside a $10 \mathrm{~km}$ radius around the station. This is in agreement with the previous finding, confirming that guiding development to areas located near transit stations was not the approach adopted by the LMA's municipalities in the 1990s.

\section{Conclusion}

The aim of this study was to address whether proximity to public transit stations played a role in projected land-use conversion in PDMs that were approved in the 1990s and are still in force today. This work has two obvious shortcomings. First, public regulation was examined only through PDMs. One may claim that this gives a narrow view of public action, because TOD policies and land-use regulations may be implemented by the use of very diverse methods (Quigley and Rosenthal 2005, Cervero et al. 2002) far beyond the simple functional zoning approach. Second, expansion areas were considered here as if there were no discrepancy between them, while the permitted heights and densities are in fact different. A more detailed analysis would provide additional information about PDMbased projected urban forms. However, such a study must be implemented on a case-by-case basis, since there is no standard nomenclature within PDMs' land-use categories.

Still, this study allows us to underline two important conclusions. On the one hand, it has been shown that pressure on open land decreases with the distance to public transit stations when other variables are not controlled for. However, there is considerable room for maneuvering and possibilities for achieving better geographical distributions for new developable areas from a TOD perspective. This is illustrated within the metropolitan area by numerous wastelands located in the interstices between (sometimes central) residential neighborhoods or central stations (like Braço de Prata, between central Lisbon and the famous Oriente station). On the other hand, when site characteristics and urban dynamics are controlled for, proximity to a transit station is no longer a positive determinant of projected land-use conversion. It may have no influence, or it may even become a negative predictor. This result suggests that transit station location was not considered by PDMs as a determinant of planning options. Much more convincing are those factors related to urban dynamics and surroundings patterns.

Such results should be interpreted involving two different perspectives for planning policy. On the one hand, if a strict TOD perspective had been considered in the preparation of the PDMs, a $70 \mathrm{~km}^{2}$ land-use conversion might have been planned by municipalities near transit stations instead of artificializing more remote areas. Such a statement suggests that a better policy was possible in a strict TOD perspective, at least partially. It also demonstrates the need for metropolitan-scale appraisals of municipal decisions, while most TOD analyses focus on local study cases.

On the other hand, one might question the legitimacy of such a radical and almost ideological perspective. In fact, among the open land areas that were preserved in PDMs, despite their proximity to transit stations $(<2,000 \mathrm{~m}$, for exam- 
ple), $55.6 \%$ are strictly agricultural areas and $21.4 \%$ are forest areas, all of them located near residential areas. In Portugal, residential agriculture still plays an important and complex role in spatial and temporal organization of individuals, not only as a hobby but also as a second source of income. It contributes to a high urban and rural mix that deviates from the often-emphasized view of suburban areas as almost exclusively dedicated to commuters' housing. A view on conflicts between TOD and agri-forestry land-use is also needed.

This study should be extended, in one of three possible ways. The first one would consist of evaluating the reasons why the LMA as a whole did not adopt a TOD perspective in the 1990s and why municipalities continue to favor new developable areas in the ongoing PDMs revisions (Carranca and Castro 2011). Comparing the 1990s PDMs with those currently engaged in an ongoing revision process would be a second rewarding approach. Two have already been approved (Vila Franca de Xira in 2009, Moita in 2010), and the remaining municipalities' revision processes are expected to be completed by 2014-2015. This comparison would allow for an examination of whether the TOD perspective has been growing within the last decade in Portugal's local planning. Third, testing actual land-use conversions against PDM options in a TOD perspective would be useful, as it would explore whether TOD-friendly local policies were more effective than the others. In particular, (1) in some cases, TOD may emerge from actual territorial management, despite the fact that the PDM did not include a TOD perspective; (2) the effectiveness of growth restrictions should be investigated; sites that were not supposed to be converted in the PDM have undergone conversion, sometimes by bribery (as previously mentioned) and sometimes by the partial suspension of the PDM for the purpose of making it possible to install or enlarge industrial or touristic units. Municipal planning is thus only a possible approach, but this study has shown that it should be analyzed more systematically as a predicted variable.

\section{$7 \quad$ Acknowledgement}

This research is supported by the Portuguese Foundation for Science and Technology (FCT), under Agreement n. ${ }^{\circ}$ SFRH/ $\mathrm{BPD} / 75833 / 2011$. It benefited from the support of the international DAUME Project (Durabilité des Agricultures Urbaines Méditerranéennes), funded by Agence Nationale de la Recherche (France). The author thanks Eduarda Marques da Costa, Nuno Marques da Costa and Patrícia Abrantes (CEG, IGOT, University of Lisbon) for their assistance with the overall project, and the anonymous referees for their helpful comments and suggestions.

\section{References}

Alden, J. and A. D. R. Pires. 1996. Lisbon: Strategic planning for a capital city. Cities 13: 25-36. doi: http://dx.doi. org/10.1016/0264-2751(95)00111-5.

Anselin, L. 1988. Spatial Econometrics: Methods and Models. Dordrecht: Kluwer Academic Publishers.

Anselin, L. 2001. Spatial econometrics. In A Companion to Theoretical Econometrics, B. Baltagi (ed.). Malden, Mass.: Blackwell Publishers.

Apparicio, P., M. Abdelmajid, M. Riva, and R. Shearmur. 2008. Comparing alternative approaches to measuring the geographical accessibility of urban health services: Distance types and aggregation-error issues. International Journal of Health Geographics 7, 1-14.

Arrington, G. B. and T. Parker. 2001. Statewide transit-oriented development study: Factors for success in California. Sacramento: California Department of Transportation.

Ascher F. 2007. Les non-choix du SDRIF en font un catalogue, mais pas un projet stratégique. Pouvoirs Locaux 73: 57-60.

Banister, D. 2005. Unsustainable Transport: City Transport in the New Century. London: Routledge.

Barroso, S. 2006. O ordenamento à escala municipal. In Geografia de Portugal, vol. 4: Planeamento e Ordenamento do Território, C.A. Medeiros (ed.). Lisboa: Círculo de Leitores.

Baum-Snow, N. 2007. Did highways cause suburbanization? Quarterly Journal of Economics 122: 775-805. doi: http:// dx.doi.org/10.1162/qjec.122.2.775.

Bettencourt, H. 2009. Padróes de ocupação do solo, estrutura regional de protecção e valorização ambiental: Diagnóstico sectorial. Lisboa: CCR-LVT.

Brueckner, J. K. 1990. Growth controls and land value in an open city. Land Economics 66: 237-248. doi: http://dx.doi. org/10.2307/3146726.

Caetano, M., M. Pereira, H. Carrão, A. Araújo, A. Nunes, and V. Nunes. 2008. Cartografia temática de ocupaçãoluso do solo do Instituto Geográfico Português. Lisboa: Instituto Geográfico Português.

Carranca, M. A. and N. Castro. 2011. Dinâmica dos perimetros urbanos nos PDM revistos após a publicação do PNPOT Fase 1: Análise. Lisboa: DGOTDU.

Carrión-Flores, C. and E. G. Irwin. 2004. Determinants of Residential Land-Use Conversion and Sprawl at the RuralUrban Fringe. American Journal of Agricultural Economics 86: 889-904. doi: http://dx.doi.org/10.1111/j.00029092.2004.00641.x.

Carruthers, J. I. 2002. Evaluating the effectiveness of regulatory growth management programs. Journal of Planning Education and Research 21: 391-405. doi: http://dx.doi. 
org/10.1177/0739456X0202100404.

Caspersen, O. H., C. C. Konijnendijk, and A. S. Olafsson. 2006. Green space planning and land use: an assessment of urban regional and green structure planning in Greater Copenhagen. Danish Journal of Geography 106: 7-20. doi: http://dx.doi.org/10.1080/00167223.2006.10649553.

Catita, A. 2009. A situação actual do sistema de planeamento e gestáo territorial: uma nova era, novas responsabilidades. Inforgeo 2009: 9-15.

Cervero, R. 1984. Journal report: Light rail transit and urban development. Journal of the American Planning Association 50: 133-147. doi: http://dx.doi. org/10.1080/01944368408977170.

Cervero, R., C. Ferrell, and S. Murphy. 2002. Transit-oriented development and joint development in the United States: A literature review. Transportation Research Board of the National Academies. Washington, DC: Federal Transit Administration.

Chakir, R. and O. Parent. 2009. Determinants of land use changes: A spatial multinomial probit approach*. $\mathrm{Pa}$ pers in Regional Science 88: 327-344. doi: http://dx.doi. org/10.1111/j.1435-5957.2009.00239.x.

Curtis, C. 2008. Planning for sustainable accessibility: The implementation challenge. Transport Policy 15: 104-112. doi: http://dx.doi.org/10.1016/j.tranpol.2007.10.003.

Curtis, C. 2012. Delivering the 'D' in transit-oriented development: Examining the town planning challenge. Journal of Transport and Land Use 5: 83-99. doi: http://dx.doi. org/10.5198/jtlu.v5i3.292.

Daniels, T. L. and A. C. Nelson. 1986. Is Oregon's farmland preservation program working? Journal of the American Planning Association 52: 22-32. doi: http://dx.doi. org/10.1080/01944368608976856.

Decoursey, W. and L. Athey. 2007. Transit-Oriented DesignIllustration of TOD Characteristics. Newark, N.J.: Institute for Public Administration.

Domingues, A. (ed.) 2006. Cidade e democracia: 30 anos de transformação urbana em Portugal, Lisboa: Argumentum.

Domingues, Á. 1999. Formas e escalas da urbanização difusa-interpretação e intervenção no NO de Portugal. Inforgeo 14: 43-64.

Dowall, D. E. 1982. The suburban squeeze: land-use policies in the San Francisco Bay area. Cato Journal 2: 709-738.

Dowall, D. E. 1984. The Suburban Squeeze: Land Conversion and Regulation in the San Francisco Bay Area. Berkeley: University of California Press.

Dumbaugh, E. 2004. Overcoming financial and institutional barriers to TOD: Lindbergh station case study. Journal of Public Transportation 7: 43-68.
Duranton, G. and M. A. Turner. 2008. Urban Growth and Transportation. Toronto: University of Toronto.

Eurostat 2012. Transport: tables and figures. In European Commission (ed.). Brussels.

Fang, S., G. Z. Gertner, Z. Sun, and A. A. Anderson. 2005. The impact of interactions in spatial simulation of the dynamics of urban sprawl. Landscape and Urban Planning 73: 294-306. doi: http://dx.doi.org/10.1016/j.landurbplan.2004.08.006.

Filion, P. \& Mcspurren, K. 2007. Smart growth and development reality: the difficult co-ordination of land use and transport objectives. Urban Studies 44: 501-523. doi: http://dx.doi.org/10.1080/00420980601176055.

Fischel, W. A. 1987. The Economics of Zoning Laws: A Property Rights Approach to American Land Use Controls. Baltimore: John Hopkins University Press.

Freilich, R. H., R. J. Sitkowski, and S. D. Mennillo. 2010. From sprawl to sustainability: smart growth, new urbanism, green development, and renewable energy. Washington, DC: ABA Publishing.

Geerlings, H. \& Stead, D. 2003. The integration of land use planning, transport and environment in European policy and research. Transport Policy, 10, 187-196. doi http:// dx.doi.org/10.1016/S0967-070X(03)00020-9.

Glaeser, E. L. and B. A. Ward. 2009. The causes and consequences of land use regulation: Evidence from Greater Boston. Journal of Urban Economics 65: 265-278. doi: http:// dx.doi.org/10.1016/j.jue.2008.06.003.

Gonçalves, J. 2009. Colmatar a deriva urbanística do planeamento municipal: remediação ou oportunidade? Inforgeo 2009: 147-157.

Headicar, P. 2003. Land use planning and the management of transport demand. In Integrated Futures and Transport Choices: UK Beyond the White Paper and Transport Acts, J. Hine and J. Preston (eds.). Aldershot: Ashgate Publishing. Henderson, J. V. 1991. Optimal regulation of land development through price and fiscal controls. Journal of Urban Economics30: 64-82. doi: http://dx.doi.org/10.1016/00941190(91)90045-9.

Hosmer, D. W. and S. Lemeshow. 2004. Applied Logistic Regression (2nd ed.). London: John Wiley \& Sons.

Instituto do Ambiente. 2005. Relatório de estado do ambiente 2005. Lisboa: Instituto do Ambiente.

Irwin, E. G., K. P. Bell, and J. Geoghegan. 2003. Modelling and managing urban growth at the rural-urban fringe: a parcel-level model of residential land use change. Agricultural and Resource Economics Review 32: 83-102.

Irwin, E. G. \& N. E. Bockstael. 2004. Land use externalities, open space preservation, and urban sprawl. Regional Sci- 
ence and Urban Economics 34: 705-725. doi: http://dx.doi. org/10.1016/j.regsciurbeco.2004.03.002.

Kline, J. D. and R. J. Alig. 1999. Does land use planning slow the conversion of forest and farmlands? Growth and Change 30: 3-22. doi: http://dx.doi.org/10.1111/00174815.00102 .

Levine, J. 2006. Zoned Out: Regulation, Markets, and Choices in Transportation and Metropolitan Land-Use. Washington, DC: RFF Press.

Lichtenberg, E. 2011. Open space and urban sprawl: the effects of zoning and forest conservation regulations in Maryland. Agricultural and Resource Economics Review 40: 393-404.

Lima, I. G. S. 2011. A corrupção participada na administração local em Portugal (2004-2008). Tese de Mestrado em Política Comparada, Universidade de Lisboa.

Magalhäes, M. R. 2001. A arquitectura paisagistica —morfologia e complexidade. Lisboa: Editorial Estampa.

Marques da Costa, N. 2007. Mobilidade e Transporte em Areas Urbanas, O caso da Area Metropolitana de Lisboa. $\mathrm{PhD}$, Universidade de Lisboa.

Marques da Costa, E., J. M. Simoes, and S. Barroso. 2009. Sistema urbano, habitação e equipamentos: diagnóstico sectorial. Lisboa: CCR-LVT.

Mayer, C. J. and C. T. Somerville. 2000. Land use regulation and new construction. Regional Science and Urban Economics 30: 639-662. doi: http://dx.doi.org/10.1016/S01660462(00)00055-7.

Melia, S., G. Parkhurst, and H. Barton, H. 2011. The paradox of intensification. Transport Policy 18: 46-52. doi: http:// dx.doi.org/10.1016/j.tranpol.2010.05.007.

Millward, H. 2006. Urban containment strategies: A casestudy appraisal of plans and policies in Japanese, British, and Canadian cities. Land Use Policy 23: 473-485. doi: http://dx.doi.org/10.1016/j.landusepol.2005.02.004.

Munneke, H. J. 2005. Dynamics of the urban zoning structure: An empirical investigation of zoning change. Journal of Urban Economics 58: 455-473. doi: http://dx.doi. org/10.1016/j.jue.2005.07.001.

Olaru, D., B. Smith, and J. H. E. Taplin. 2011. Residential location and transit-oriented development in a new rail corridor. Transportation Research Part A: Policy and Practice 45: 219-237. doi: http://dx.doi.org/10.1016/j. tra.2010.12.007.

Pardal, S. 2002. Planeamento do espaço rústico: as irracionalidades da RAN e da REN. Lisboa: ADISA-CESUR.

Pardal, S. (ed.) 2004. Estudo sobre o novo diploma para a RAN, REN e disciplina da construção fora dos perímetros urbanos. Lisboa: Instituto Superior de Agronomia, Universidade Técnica de Lisboa.
Pendall, R. 2000. Local land-use regulation and the chain of exclusion. Journal of the American Planning Association 66, 125-142. doi: http://dx.doi. org/10.1080/01944360008976094.

Pendall, R., Martin, J. \& Fulton, W. 2002. Holding the line: urban containment in the United States. Washington, DC: The Brookings Institution Center on Urban and Metropolitan Policy.

Péres, S. and N. Gaussier. 2010. La conversion de parcelles viticoles en usage résidentiel: le cas de l'aire urbaine de Bordeaux. Canadian Journal on Regional Science 33: 123-136.

Portas, N., A. Domingues, and J. Cabral. 2007. Políticas urbanas: tendências, estratégias e oportunidades. Lisboa: FCG.

Portas, N., Á. Domingues, and J. Cabral. 2011. Políticas urbanas II: transformaçóes, regulação e projectos. Lisboa: FCG.

Quigley, J. M. and L. A. Rosenthal. 2005. The effects of land use regulation on the price of housing: What do we know? What can we learn? Cityscape: a Journal of Policy Development and Research 8: 69-137.

Renne, J. L. 2008. From transit-adjacent to transit-oriented development. Local Environment 14: 1-15. doi: http:// dx.doi.org/10.1080/13549830802522376.

Renne, J. L. and J. Wells. 2005. Transit-oriented development: Developing a strategy to measure success. Washington, DC: Transportation Research Board.

Sanchez, T. W. 2004. Land use and growth impacts from highway capacity increases. Journal of Urban Planning and Development 130: 75-82. doi: http://dx.doi.org/10.1061/ (ASCE)0733-9488(2004)130:2(75).

Searle, G. 2007. Sydney's urban consolidation experience: Power, politics and community, Brisbane: Griffith University.

Soares de Albergaria, C. A. 2006. Um olhar critico sobre o conceito e a prática da Reserva Ecológica Nacional. Tese de Mestrado: Universidade do Porto.

Soares, L. J. B. 2003. Ordenamento e planeamento do território no contexto metropolitano. In Atlas da Área Metropolitana de Lisboa, J. A. Tenedório (ed.). Lisboa: Área Metropolitana de Lisboa.

Stead, D. E. Meijers. 2009. Spatial planning and policy integration: Concepts, facilitators and inhibitors. Planning Theory \& Practice 10: 317-332.

Swaffield, S. and J. Primdahl. 2006. Spatial concepts in landscape analysis and policy: Some implications of globalisation. Landscape Ecology 315-331. doi: http://dx.doi. org/10.1007/s10980-004-4414-6.

Tabachnick, B. G. and L. S. Fidell. 2000. Using multivariate statistics (4th ed.). Boston: Allyn \& Bacon.

Towe, C. A., C. J. Nickerson, and N. Bockstael. 2008. An empirical examination of the timing of land conversions in 
the presence of farmland preservation programs. American Journal of Agricultural Economics 90: 613-626. doi: http:// dx.doi.org/10.1111/j.1467-8276.2007.01131.x.

United Nations Development Programme. 2004. Human development report. New York: UNDP.

Vejre, H., J. Primdahl, and J. Brandt. 2007. The Copenhagen Finger Plan: keeping a green space structure by a simple planning metaphor. In Europe's living landscapes: Essays on exploring our identity in the countryside, B. Pedroli, A. Van Doorn, G. de Blust, M. L. Paracchini, D. Wascher, and D. Bunce (eds.). Zeist: KNNV Publishing.

Williams, K., E. Burton, and M. Jenks (eds.). 2000. Achieving sustainable urban forms. London: E\&FN Spon.

Woodcock, I., K. Dovey, S. Wollan, and I. Robertson. 2011. Speculation and resistance: Constraints on compact city policy implementation in Melbourne. Urban Policy and Research 29: 4: 343-362.

Wu, J. and S.-H. Cho. 2007. The effect of local land use regulations on urban development in the Western United States. Regional Science and Urban Economics 37: 69-86. doi: http://dx.doi.org/10.1016/j.regsciurbeco.2006.06.008.

Yigitcanlar, T., N. G. Sipe, R. Evans, and M. Pitot. 2007. A GIS-based land use and public transport accessibility indexing model. Australian Planner 44: 30-37. doi: http:// dx.doi.org/10.1080/07293682.2007.9982586. 